\title{
Basic Life Support awareness among resident doctors, medical students, nursing experts, health care providers, and their assistants in Southwest Iran
}

\section{Znajomość podstawowych zabiegów resuscytacyjnych wśród lekarzy rezydentów, studentów medycyny, pielęgniarek, pracowników służby zdrowia i personelu pomocniczego $w$ potudniowo-zachodnim Iranie}

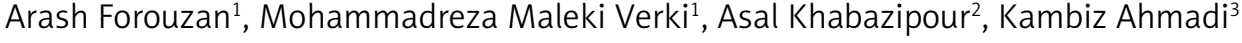 \\ ${ }^{1}$ Department of Emergency Medicine, Ahvaz Jundishapur University of Medical Sciences, Ahvaz, Iran \\ Head of the Department: Dr. Hassan Motamed \\ ${ }^{2}$ General Physician, Ahvaz Jundishapur University of Medical Sciences, Ahvaz, Iran \\ Head of the Department: Dr. Seyed Saeed Seyedian \\ ${ }^{3}$ Department of Statistics and Epidemiology, Faculty of Public Health, Ahvaz Jundishapur University of Medical Sciences, Ahvaz, Iran \\ Head of the Department: Dr. Abdolkazem Neisi
}

Key words: awareness, BLS education, cardiopulmonary resuscitation, knowledge.

Słowa kluczowe: świadomość, edukacja na temat BLS, resuscytacja krążeniowo-oddechowa, wiedza, umiejętności.

\begin{abstract}
Introduction: Knowing the basic life support (BLS) technique is an essential requirement for all individuals of a community in order to save lives in an emergency. The awareness level about the proper techniques of BLS is questionable among medical personnel. Aim of the research: This prospective observational study was conducted to assess the awareness level of the basic resuscitation principles in Southwest Iran.

Material and methods: The aspects that were asked in this questionnaire include the following items: the basic resuscitation stages, and methods of assessment and resuscitation with regard to airway, respiration, and blood circulation in the victims according to age group.

Results: In total, 202 people employed in the hospital participated in this study. The mean scores of those who had already completed BLS education was $8.45 \pm 2.42$ and in the individuals who had heard about these technique it was $7.31 \pm 2.71(p=$ $0.002)$. This relation was statistically significant. The knowledge of specialised assistants was significantly higher than health care providers and their assistants as well as medical intern groups $(p<0.001)$. In addition, the knowledge of nursing experts was significantly higher than the health care providers and their assistants $(p=0.004)$ and medical interns $(p=0.002)$.

Conclusions: This study showed that the awareness level of the cardiopulmonary resuscitation principles among different health care departments (health care providers, nurses, and physicians) is low, and holding education courses with a minimum of 6-month intervals is necessary. In addition, for medical interns, basic medical education should start from basic medical sciences.
\end{abstract}

\section{Streszczenie}

Wprowadzenie: Znajomość podstawowych zabiegów resuscytacyjnych (BLS) to podstawowy wymóg dla wszystkich osób, które zajmują się ratowaniem życia w nagłych przypadkach. Poziom znajomości tych technik wśród personelu medycznego budzi wątpliwości.

Cel pracy: Prospektywne badanie obserwacyjne przeprowadzono w celu oceny znajomości podstawowych zasad resuscytacji w południowo-zachodnim Iranie.

Materiał i metody: Pytania w kwestionariuszu dotyczyły takich zagadnień, jak podstawowe etapy i metody resuscytacji, metody oceny dróg oddechowych, oddychania i krążenia krwi u ofiar w zależności od grupy wiekowej.

Wyniki: Łącznie w badaniu uczestniczyły 202 osoby zatrudnione w szpitalu. Średnie wyniki osób, które ukończyły edukację na temat BLS, wynosiły $8,45 \pm 2,42$, a osób, które słyszały o tych technikach $-7,31 \pm 2,71(p=0,002)$. Różnica była statystycznie istotna. Znajomość technik BLS wśród wyspecjalizowanych ratowników była znacznie wyższa niż wśród pracowników ochrony zdrowia i personelu pomocniczego oraz stażystów $(p<0,001)$. Ponadto wiedza pielęgniarek była znacznie wyższa niż pracowników ochrony zdrowia i personelu pomocniczego $(p=0,004)$ oraz stażystów $(p=0,002)$. 
Wnioski: W badaniu wykazano, że znajomość zasad resuscytacji krążeniowo-oddechowej w różnych działach opieki zdrowotnej (pracownicy ochrony zdrowia, pielęgniarki i lekarze) jest niska. W związku z tym konieczne jest prowadzenie kursów edukacyjnych co 6 miesięcy. Ponadto edukacja w przypadku stażystów powinna się rozpoczynać od podstawowych nauk medycznych.

\section{Introduction}

Cardiopulmonary arrest (CPA) is a sudden respiratory stop or an effective blood circulation in patients, with the exception of patients with advanced and end stages of chronic illnesses and cancer [1].

According to the statistics of the World Health Organisation, cardiovascular disease is currently the most important and the most common cause of death in the world; in 2012 about 17.5 million people $(46 \%$ of all deaths due to non-contagious diseases) died because of cardiovascular illness [2]. Furthermore, according to published statistics by the US Health and Medical Organisation, annually 300,000 people die due to cardiovascular disease in this country [3].

Basic life support (BLS) is a key component of the resuscitation process, which improves the survival chances of patients with cardiac arrest. Since the central nervous system, after a period of more than 3-4 min of hypoxia and/or lack of oxygen, can cause irreversible damage, the onset of non-delayed and high-quality BLS can greatly improve the survival chances of patients [4].

In this regard, the American Heart Association recommends the use of a survival chain for all patients requiring cardiopulmonary resuscitation (CPR). The links in this chain include rapid diagnosis of disease requiring $\mathrm{CPR}$, fast and timely performance of $\mathrm{CPR}$, fast and timely use of a defibrillator, advanced resuscitation measures, and post heart attack care [5]. Among the above-mentioned items, are the first three steps of resuscitation of initial resuscitation measures [6].

Knowing the BLS technique is essential for all individuals within the community in order to save lives in an emergency. Among all the community groups, it is at least expected that the staff involved in medical and paramedical sciences are educated about using CPRs to a good level.

Studies show that if CPR is done by highly-skilled and trained people with minimum delay, it leads to reduction of mortality [7]. In the United States, BLS training has been recommended for all health care professionals since 1966 [8]. Since the late 1980s, numerous studies have been done on the knowledge and skills of performing CPR. Some of these studies showed the effect of the presence of trained people on the process of resuscitation. Based on the results of one of these studies, even the presence of one person with more skill can have a tremendous effect on the resuscitation process $[9,10]$.

Despite the importance of CPR, a recent study in Iran showed that only $9.7 \%$ of the medical treatment staff had the required skills in this regard [11, 12]. In
Iran, although BLS education has been increasingly a part of the curriculum for medical and nursing students, the awareness level about the proper techniques of BLS is questionable among medical personnel.

\section{Material and methods}

\section{Design and studied population}

This prospective observational study was conducted according to the Strengthening the Reporting of Observational Studies in Epidemiology (STROBE) [13] from April 8, 2017 to July 17, 2017, After obtaining Ethics Committee approval from Ahvaz Jundishapur University and written consent.

\section{Study method}

During the period of this study, questionnaires were distributed to participants working hospital in Ahvaz. The current study questionnaire was set forth according to the new guidelines of the American Heart Association after reviewing previous studies [7, 14].

This questionnaire consists of 18 questions in two parts. The first part contains demographic information about the age, gender, field of study, and the history of participation in BLS formal education courses, as well as a second part, which includes 0-18 scores (Appendix). The questioned aspects included the following items: the preliminary stages of resuscitation, assessment and resuscitation techniques in relation to the airway, respiration, and blood circulation in the victims according to the age group, which, in a total of seven questions, referred to the principles of external massage of the chest. In addition, five questions were specifically devoted to airway management, and a joint question assessed the knowledge in both areas.

The content validity method was used to assess the validity of the questionnaire.

Then, 10 copies of this questionnaire were distributed among 6 faculty members of the hospital and four of the educated CPR nurses. Finally, 10 copies of this questionnaire were given to medical students and professional medical assistants, and their corrective comments were ultimately applied in the final compilation of the questionnaire.

\section{Statistical analysis}

The reliability of the questionnaire was analysed by SPSS software using Cronbach's $\alpha$ coefficient with $\alpha=0.75$. Number 1 was assigned for the correct option, 0 for the wrong option, and 2 was used for unanswered questions. Data were extracted and analysed 


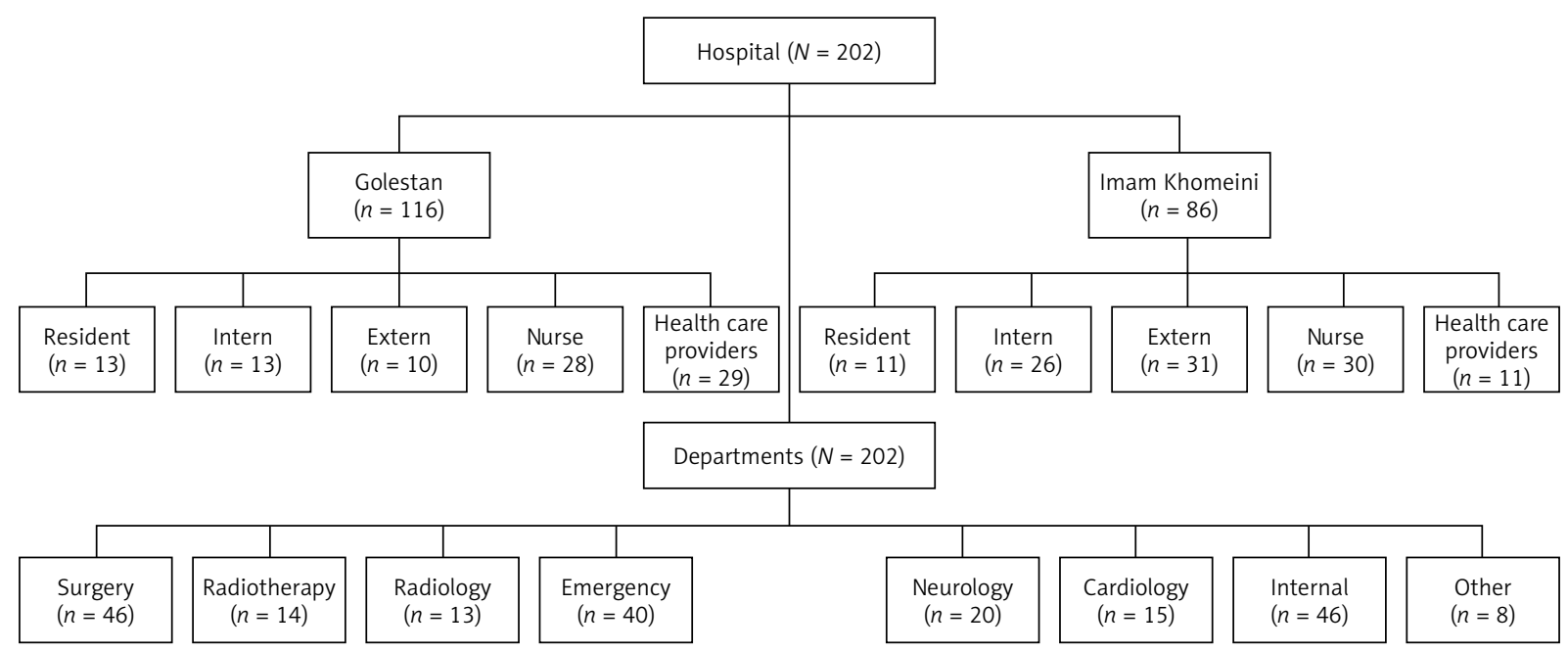

Figure 1. Flow diagram chart

by descriptive statistics, independent $t$-test, and Pearson correlation coefficient.

\section{Results}

In total, 202 people participated in this study (Figure 1); among them, 131 (64.9\%) were female. The average age of participants was $30.22 \pm 8.44$ years. The education level of studied population included resident doctors undergoing education (11.9\%), medical interns (19.3\%), medical externs (20.3\%), nursing experts $(28.7 \%)$, and health care providers (19.8\%). In total, 109 $(54.0 \%)$ of the participants in this study successfully passed the course of the previous CPR (Table 1).

The results showed that the average obtained scores in the total population was $7.93 \pm 2.61$, the highest score was 15, and the lowest score was 1 (Figure 2).

$34.7 \%$ of participants responded correctly to half or more than half of the questions about the principles

Table 1. Demographic characteristics of the study population

\begin{tabular}{|lc|}
\hline Parameter & Value \\
\hline Gender, $n(\%):$ & $71(35.1)$ \\
\hline Male & $131(64.9)$ \\
Age, mean \pm SD [years] & $30.22 \pm 8.44$ \\
Professional status, $n(\%):$ & \\
\hline Resident doctors & $24(11.9)$ \\
\hline Intern & $39(19.3)$ \\
\hline Extern & $41(20.3)$ \\
\hline Nurse & $58(28.7)$ \\
\hline Health care providers & $40(19.8)$ \\
Previous exposure to BLS, $n(\%)$ & $109(54)$ \\
\hline
\end{tabular}

of external chest massage. This rate regarding ventilation principles was significantly lower $(p=0.001)$ and was reported at $15.3 \%$.

\section{The relationship between gender and mean scores}

The average test scores for women was $8.15 \pm 2.52$ and in men was $7.52 \pm 2.74$; no significant difference was seen among the respondents' scores $(p=0.15)$.

\section{The relationship between education} and mean scores

The mean scores of people who had already passed BLS education courses was $8.45 \pm 2.45$ and non-educated persons was $7.31 \pm 2.71$ in $(p=0.002)$. This relationship was statistically significant.

\section{Relationship between the level of education and the awareness level of CPR}

The results show that resident doctors ( 24 people) attained the highest score in this test (9.58), and for

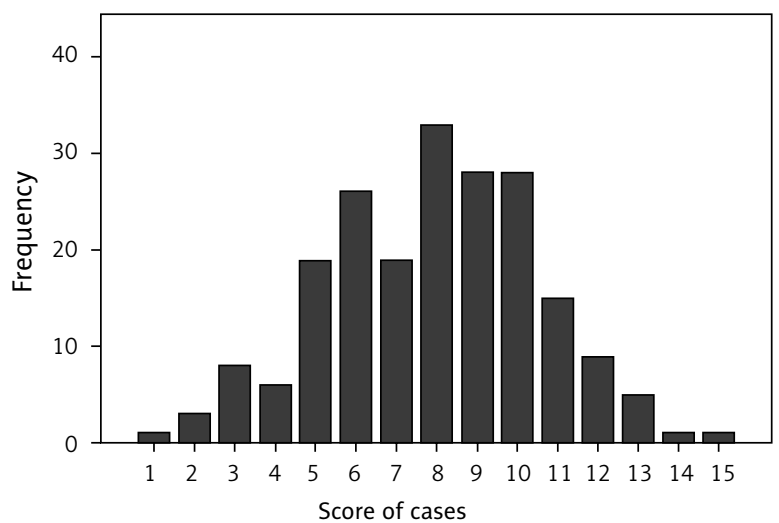

Figure 2. The average obtained scores in the total population 


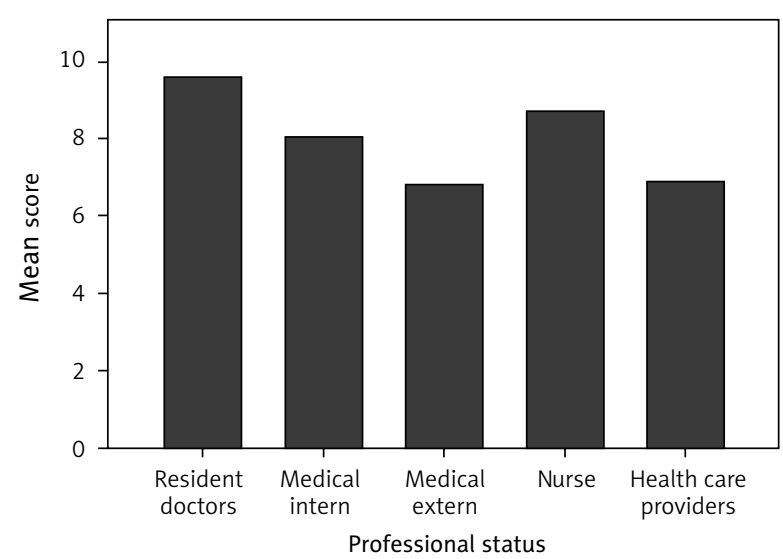

Figure 3. Relationship between the level of education and the awareness level of CPR

the next categories: nursing experts (58 people) scored 8.69, medical interns (39) scored 8.05, and health care providers and their assistants (40 people) scored 6.88 . The last group, medical externs (41 people), scored 6.80 (Figure 3).

Knowledge of specialised assistants was significantly higher than the health care providers, their assistants groups $(p<0.001)$, and medical students $(p<0.001)$. In addition, the knowledge of nursing experts was significantly higher than the health care providers, their assistants $(p=0.004)$, and medical students $(p=0.002)$.

\section{Discussion}

Cardiopulmonary resuscitation has always been considered as one of the most important factors in protecting the lives of patients with CPA; its correct and timely performance can save these patients to a large extent from certain death [15]. It seems that having good knowledge of the theory is an important prerequisite for successful CPR.

Various studies in different countries indicate that, in general, the theory of knowledge is in the context of the resuscitation of the base; in a study conducted in India on 1054 people from different medical courses $894(84.82 \%)$ participants had a score of less than 50\% [16]. Similarly, in foreign studies, similar results have been reported in domestic studies. As an example, a study conducted on nurses' knowledge about CPR showed that their mean scores for theoretical and practical knowledge is $48 \%$ [17].

The low level of theoretical knowledge seems to be partly explained by the fact that only $54 \%$ of the respondents who participated in our study were educated with CPR-related courses. According to various studies, lack of or non-continuing education is one of the main causes of low scores among the majority of students in various studies. In the study conducted by
Plagisou et al., only $13.2 \%$ of respondents in the past 6 months participated in a CPR course [7].

Mellor et al., examined the role of education in the knowledge level about BLS in 34 health workers who had been tested before and after participation in a BLS education course [18].

It was showed that after passing the education course, a significant improvement was made in the correct actions and safe approach of the participants. In all cases, including checking the response, asking for help, opening the airway, checking the breathing, asking help from the heart resuscitation team, having the appropriate breathing rate, making appropriate heart resuscitation, making appropriate heart massage, doing massage with appropriate depth and the number of massages per minute, significant progress has been made.

Smith et al. examined the ability to maintain theoretical knowledge and performance of nurses in relation to BLS and advanced cardiovascular life support (ACLS), and they showed that the theory of knowledge and practical skills of resuscitation rapidly reduce over time. Regarding BLS, after three months of education, the number of accepted people in the test was $63 \%$, and after 12 months it reduced to 58\% [19].

Of these studies, it can be concluded that although doctors and nurses participate in CPR education programs during their employment and education period, participating in education courses every 6 months leads to preservation of knowledge and theoretical skills. This issue indicates the need for continuing education $[20,21]$.

Our study showed that, although there is a serious shortage of knowledge about BLS, this shortage among the groups of medical interns, assistant nurses, and health care providers was worse. In addition, the results of Reddy et al.'s study indicated that there is insufficient knowledge about BLS among different groups. It is required that the knowledge and skills associated with BLS are increased, as well as holding courses and workshops to update their information [22]. A similar study showed that the average response to questions in the field of theoretical knowledge in medical and nursing fields was significantly higher than among public health students (non-therapeutic) (60\% vs. $45 \%$, respectively) [23]. One of the cases found in this study was the lack of knowledge among medical students in internship in comparison with other respondents - they gained the lowest scores.

The evaluations suggested that the cause of lower score in this category of people may be related to less educating of students. The importance of this issue is because some studies indicate that medical interns who passed CPR programs in their early education years, compared to other practitioners who study CPR in their late years of study, are more willing to improve their knowledge and skills [24, 25]. In addition, Aroor showed that having knowledge about 
BLS consecutively can be increased during the different educational levels. This matter shows the need to strengthen and refresh BLS education courses at regular intervals [26].

The results of our study showed that $34.7 \%$ of participants responded correctly to half or more than half of the questions about the principles of external chest massage. This rate regarding ventilation principles was reported significantly lower, at $15.3 \%$. These results were similarly reported in the study by Baduni et al.; in this study, $32.11 \%$ of the participants responded correctly to questions about the external massage of the chest. This figure for respiration and making an airway was merely $17.49 \%$ [1]. Similarly, in the study conducted by Alotaibi et al., $45.52 \%$ of respondents responded to questions about the external chest massage, and $25.92 \%$ of respondents responded correctly to the question about respiration problems [27].

From all the studies, it can be concluded that theoretical knowledge about breathing and making an airway occur in less time in comparison with chest massage. Perhaps the cause of this reduced knowledge is due to the lower importance of the airway in comparison with chest massages in resuscitation. Because it seems that some CPR volunteers are unwilling to do it, they probably would not feel the need to learn about this matter. On the other hand, in the recent edition, mouth-to-mouth breathing has also been optionally mentioned.

\section{Conclusions}

This study showed that the knowledge level about CPR among different health care departments (physicians, nurses, and health care providers) is low and the need for continuing education courses with a minimum of 6-months intervals is necessary. In addition, for medical students, CPR should start from basic medical sciences. Further emphasis on the importance of airway ventilation training in the codified courses should be considered as part of the basic principles of resuscitation.

\section{Conflict of interest}

The authors declare no conflict of interest.

\section{References}

1. Baduni N, Prakash P, Srivastava D, Sanwal MK, Singh BP. Awareness of basic life support among dental practitioners. Natl J Maxillofac Surg 2014; 5: 19-22.

2. Organization WH. Global Health Observatory: non-communicable diseases mortality and morbidity. 2013.

3. Writing Group Members, Mozaffarian D, Benjamin EJ, Go AS, Arnett DK, Blaha MJ, Cushman M, Das SR, de Ferranti S, Després JP, Fullerton HJ, Howard VJ, Huffman MD, Isasi CR, Jiménez MC, Judd SE, Kissela BM, Lichtman JH, Lisabeth LD, Liu S, Mackey RH, Magid DJ, McGuire DK, Mohler ER 3rd, Moy CS, Muntner P, Mus- solino ME, Nasir K, Neumar RW, Nichol G, Palaniappan L, Pandey DK, Reeves MJ, Rodriguez CJ, Rosamond W, Sorlie PD, Stein J, Towfighi A, Turan TN, Virani SS, Woo D, Yeh RW, Turner MB; American Heart Association Statistics Committee; Stroke Statistics Subcommittee. Heart Disease and Stroke Statistics-2016 Update: A Report From the American Heart Association. Circulation 2016; 133: e38-360.

4. Sasson C, Rogers MA, Dahl J, Kellermann AL. Predictors of survival from out-of-hospital cardiac arrest: a systematic review and meta-analysis. Circulation Cardiovasc Qual Outcomes 2010; 3: 63-81.

5. Kleinman ME, Brennan EE, Goldberger ZD, Swor RA, Terry M, Bobrow BJ, Gazmuri RJ, Travers AH, Rea T. Part 5: Adult Basic Life Support and Cardiopulmonary Resuscitation Quality: 2015 American Heart Association Guidelines Update for Cardiopulmonary Resuscitation and Emergency Cardiovascular Care. Circulation. 2015; 132 (18 Suppl 2): S414-S435.

6. Neumar RW, Eigel B, Callaway CW, Estes NA $3^{\text {rd }}$, Jollis JG, Kleinman ME, Morrison LJ, Peberdy MA, Rabinstein A, Rea TD, Sendelbach S; American Heart Association. American Heart Association Response to the 2015 Institute of Medicine Report on Strategies to Improve Cardiac Arrest Survival. Circulation 2015; 132: 1049-1070.

7. Plagisou L, Tsironi M, Zyga S, Moisoglou I, Maniadakis N, Prezerakos P. Assessment of nursing staff's theoretical knowledge of cardiovascular resuscitation in an NHS public hospital. Hellenic J Cardiol 2015; 56: 149-153.

8. Resuscitation C. Statement by the Ad Hoc Committee on Cardiopulmonary Resuscitation of the Division of Medical Sciences. National Academy of Sciences-National Research Council. JAMA 1966; 198: 372-379.

9. Taffet GE, Teasdale TA, Luchi RJ. In-hospital cardiopulmonary resuscitation. JAMA 1988; 260: 2069-2072.

10. Tyrer F, Williams M, Feathers L, Faull C, Baker I. Factors that influence decisions about cardiopulmonary resuscitation: the views of doctors and medical students. Postgrad Med J 2009; 85: 564-568.

11. Mahmoodpoor A, Soleimanpour H, Nia KS, Panahi JR, Afhami M, Golzari SE, Majani K. Sensitivity of palm print, modified mallampati score and 3-3-2 rule in prediction of difficult intubation. Int J Prev Med 2013; 4: 1063-1069.

12. Saghizadeh M, Rahmani A, Ahangharzadeh Rezaie S. Investigation of nurse's knowledge and practice working in CCU Wards of Taleghani Hospital of Urmia University of Medical Sciences regarding adult Cpr, 1383. J Urmia Nurs Midwifery Fac 2006; 4: 99-103.

13. von Elm E, Altman DG, Egger M, Pocock SJ, Gotzsche PC, Vandenbroucke JP; STROBE Initiative. The Strengthening the Reporting of Observational Studies in Epidemiology (STROBE) Statement: guidelines for reporting observational studies. Int J Surg 2014; 12: 1495-1499.

14. Xanthos T, Akrivopoulou A, Pantazopoulos I, Aroni F, Datsis A, Iacovidou N. Evaluation of nurses' theoretical knowledge in basic life support: a study in a district Greek hospital. Int Emerg Nurs 2012; 20: 28-32.

15. Sandroni C, Nolan J, Cavallaro F, Antonelli M. In-hospital cardiac arrest: incidence, prognosis and possible measures to improve survival. Intensive Care Med 2007; 33: 237-245. 
16. Chandrasekaran S, Kumar S, Bhat SA. Awareness of basic life support among medical, dental, nursing students and doctors. Indian J Anaesthesia 2010; 54: 12-126.

17. Bakhsha F, Behnampour N. The effect of CPR training on knowledge of nurses working in the hospitals affiliated to Golestan University of Medical Sciences. J Gorgan Univ Med Sci 2007; 8: 46-49.

18. Mellor R, Woollard M. Skill acquisition by health care workers in the Resuscitation Council (UK) 2005 guidelines for adult basic life support. Int Emerg Nurs 2010; 18: 61-66.

19. Smith KK, Gilcreast D, Pierce K. Evaluation of staff's retention of ACLS and BLS skills. Resuscitation 2008; 78: 59-65.

20. Hopstock LA. Cardiopulmonary resuscitation; use, training and self-confidence in skills. A self-report study among hospital personnel. Scand J Trauma Resusc Emerg Med 2008; 16: 18

21. Nyman J, Sihvonen M. Cardiopulmonary resuscitation skills in nurses and nursing students. Resuscitation 2000; 47: $179-184$.

22. Reddy S, Doshi D, Reddy P, Kulkarni S, Reddy S. Awareness of basic life support among staff and students in a dental school. J Contemp Dent Pract 2013; 14: 511-517.

23. Saffari M, Amini N, Pakpour AH, Sanaeinasab H. Assessment the medical sciences students knowledge and skill about basic cardiopulmonary resuscitation (CPR) in accidents and disasters. Iran J Health Educ Health Promotion 2013; 1: 41-50.

24. Chowdari A, Niranjan G, Dinesh B. A cross-sectional study on awareness and perception about basic life support/ cardio-pulmonary resuscitation among undergraduate medical students from coastal South India. Int J Med Public Health 2013; 3: 146-150.

25. Yunus M, Mishra A, Karim HM, Raphael V, Ahmed G, Myrthong CE. Knowledge, attitude and practice of basic life support among junior doctors and students in a tertiary care medical institute. Int J Res Med Sci 2017; 3: 3644-50.

26. Aroor AR, Saya RP, Attar NR, Saya GK, Ravinanthanan M Awareness about basic life support and emergency medical services and its associated factors among students in a tertiary care hospital in South India. J Emerg Trauma Shock 2014; 7: 166-179.

27. Alotaibi O, Alamri F, Almufleh L, Alsougi W. Basic life support: knowledge and attitude among dental students and Staff in the College of Dentistry, King Saud University. Saudi J Dental Res 2016; 7: 51-56.

\section{Address for correspondence:}

\section{Mohammadreza Maleki Verk}

Department of Emergency Medicine

Ahvaz Jundishapur University

of Medical Sciences

Ahvaz, Iran

Phone: +98 6133921637

E-mail: drmalaki676@yahoo.com 


\section{Appendix}

Hospital............................... Department............................... Gender.......... Age........... Education level............ Have you ever been educated in the field of cardiopulmonary resuscitation (CPR) principles? Yes................... No...................

1. What will be your first action in dealing with someone who had an accident in the road and does not respond to you?
A. Opening the airway
C. Paying attention to your safety
B. Starting a heart massage
D. Giving him/her two breaths

2. If you are at the patient's bedside and do not receive an answer after shaking and calling him/her, what is your next action?
A. Starting a heart massage
C. Putting the injured person in improvement situation

B. Calling emergency 115

D. Watching the person

3. Where is the right place for heart massage on the chest?
A. Left side of the chest
B. Right side of the chest
C. The middle part of the chest
D. The junction area of xiphoid to sternum

4. Where is the right place for heart massage on the chest, in babies?
A. A knuckle width under the line connecting the tips of the two breasts
B. As the size of a knuckle width upper the line
C. The middle part of the line connecting the tips of the two nipples
D. Connection area of xiphoid to sternum connecting the tips of two nipples

5. If you do not intend to perform mouth-to-mouth breathing while you are resuscitating, which of the following actions cannot be done:
A. Ventilation with oral mask and heart massage
C. Ventilation with bag mask with heart massage
B. Only heart massage
D. We do not resuscitate

6. How do you breathe newborn during cardiopulmonary resuscitation (CPR)?
A. Breathing mouth to mouth with obstruct the nose
C. Only through the mouth to nose
B. From mouth to mouth and nose
D. From mouth to mouth without obstruct nose

7. What is the depth of chest pressing in adults during resuscitation?
A. $2-3 \mathrm{~cm}$
C. $5-6 \mathrm{~cm}$
B. $4-5 \mathrm{~cm}$
D. $6-7 \mathrm{~cm}$

8. What is the depth of chest pressing in children during resuscitation?
A. $2-3 \mathrm{~cm}$
C. $4-5 \mathrm{~cm}$
B. $3-4 \mathrm{~cm}$
D. $5-6 \mathrm{~cm}$

9. What is the speed of chest pressing in adults and children during CPR:
A. $80-100$ per minute
C. $120-140$ per minute
B. $100-120$ per minute
D. $140-160$ per minute

10. What is the ratio of heart massage number to the respiration number in CPR:
A. 15 to 2
C. 30 to 2
B. 5 to 1
D. 15 to 1

11. If you are faced with an adult with no response, overwhelming in water and you getting him/her out of the water. He/she is breathing but still has no response. What is the first step?
A. Resuscitation for 2 min and notifying emergency 115
C. Pressing the abdomen to drain the water
B. Resuscitation for $1 \mathrm{~min}$ and notifying emergency 115
D. Putting the exhilarating in improving condition

12. If you are faced with a person without response. How long will you spend checking the carotid pulse of this person?

A. 5 to $10 \mathrm{~s}$

C. $15 \mathrm{~s}$

B. 10 to $15 \mathrm{~s}$

D. $20 \mathrm{~s}$ 


\section{Which one of the following is the correct sequence of CPR?}

A. Response assessment, help request, checking the C. Checking of carotid pulse and respiratory pulses, carotid pulse and breathing

B. Asking for help, evaluating the response, checking the carotid pulse and breathing

asking for help, assessment of response

D. Response evaluation, checking carotid pulse and respiration, asking for help

\section{In the resuscitation operation, which of the following pulses is checked?}
A. Radial
C. Femoral
B. Carotid
D. No different

15. If you encounter a patient with no response, the patient is not breathing but has carotid pulse, what is your next action?

A. Every $6 \mathrm{~s}$ a breath should be given, and every $2 \mathrm{~min}$ the carotid pulse should be checked

B. Every $10 \mathrm{~s}$ a breath should be given, and every $4 \mathrm{~min}$ the carotid pulse should be checked

C. Every $6 \mathrm{~s}$ only one breath should be given

D. Every $6 \mathrm{~s}$ two breaths should be given, and every $2 \mathrm{~min}$ the carotid pulse should be checked

\section{What is the proper breathing in CPR:}

A. Common exhale, two seconds breathing with the aim of raising the chest

B. Common exhale, one second breathing with the goal of raising the chest

C. Common inhale, two seconds breathing with the aim of raising the chest

D. Common inhale, breathing time of one second with the goal of raising the chest

\section{What is ABED an abbreviation for?}
A. Auto Defibrillator
B. Automatic Electric Defibrillator
C. Advanced Defibrillator
D. Advanced External Defibrillator

18. Which cardiac massage features are correctly mentioned?

A. Medium pressing without letting the chest return to the first state at the right speed

B. Quick pressing, letting chest return to the first state of proper speed
C. Medium pressing with letting chest back to the first state of proper speed

D. Fast pressing without letting the chest back to the first state of proper speed 